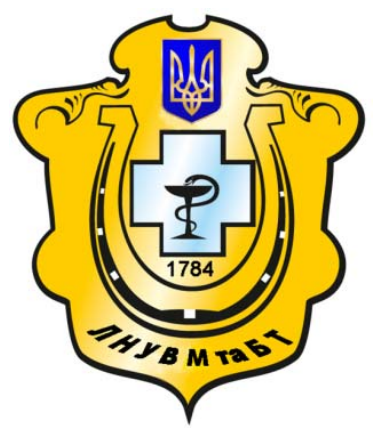

Науковий вісник Львівського національного університету ветеринарної медицини та біотехнологій імені С.3. Гжицького

Scientific Messenger of Lviv National University of Veterinary Medicine and Biotechnologies named after S.Z. Gzhytskyj

doi:10.15421/nvlvet6641

ISSN 2413-5550 print

ISSN 2518-1327 online

$\underline{\text { http://nvlvet.com.ua/ }}$

УДК 619:616.36:636.3

\title{
Показники пероксидного окиснення ліпідів у крові вівцематок, хворих на гепатодистрофію
}

\author{
Б.О. Чернушкін ${ }^{1}$, Л.Г.Слівінська ${ }^{1}$, В.В. Влізло ${ }^{1}$ \\ chernushkin@i.ua
}

${ }^{1}$ Львівський національний університет ветеринарної медицини та біотехнологій імені С.3. Гэсицького, вул. Пекарська, 50, м. Львів, 79010, Україна;

${ }^{2}$ Інститут біології тварин НААН,

вул. В. Стуса, 38, м. Львів, 79034, Украӥна

\begin{abstract}
У статті наведено результати досліджень щуодо причин виникнення та клінічного прояву гепатодистрофії у вівиематок, стан показників пероксидного окиснення ліпідів - ТБК-активних продуктів, гідропероксидів ліпідів, дієнових кон'югатів.

Основними причинами розвитку первинної гепатодистрофії у овець є незбалансована годівля та дефіцит основних поживних речовин у рачіонах. При аналізі рачіону встановлено нестачу сухої речовини, сирого протеїну, перетравного протеїну, сирої клітковини, иукру та крохмалю. Співвідношення иукру-крохмалю із перетравним протеїном складало 1,78:1, а иукро-протеїнове співвідношення - 0,77. Раціони були дефіциттними за вмістом вітамінів D $і$ E, мікроелементів - Сульфуру, Купруму, Цинку, Кобальту та Йоду. У вівиематок, хворих на гепатодистрофію, встановлено розвиток оксидаційного стресу - збільшення у крові активності ТБК-активних продуктів, гідропероксидів ліпідів, дієнових кон'югатів. Зокрема, удвічі зростала концентрачія дієнових кон'югатів, утричі підвищувалася кількість гідропероксидів ліпідів, а активність ТБК-активних продуктів зростала у п'ять разів порівняно із клінічно здоровими тваринами.

При гістологічному дослідженні біоптатів печінки хворих вівцематок встановлено розвиток білкової зернистої та жирової дистрофії гепатоцитів.

Ключові слова: вівиематки, гепатодистрофія, оксидаційний стрес, ТБК-активні продукти, гідропероксиди ліпідів, дієнові кон'юганти, гепатоцити.
\end{abstract}

\section{Показатели перекисного окисления липидов в крови овцематок, больных гепатодистрофией}

\author{
Б.О. Чернушкин ${ }^{1}$, Л.Г. Сливинска ${ }^{1}$, В.В. Влизло ${ }^{2}$ \\ chernushkin@i.ua
}

${ }^{1}$ Львовский нацииональный университет ветеринарной медицины и биотехнологий имени С.3. Гжицякого, ул. Пекарская, 50, г. Львов, 79010, Украина;

${ }^{2}$ Институт биологии животных НААН,

ул. В. Стуса, 38, г. Львов, 79034, Украина

В статье приведены результаты исследований о причинах возникновения и клинического проявления гепатодистрофии у овиематок, состояние показателей перекисного окисления липидов - ТБК-активных продуктов, гидроперекисей липидов, диеновых коньюгатов.

Основными причинами развития гепатодистрофии у овцематок является несбалансированное кормление и дефицит основных питательных веществ в рационах. При анализе раџиона установлен дефицит сухого вещества, сырого протеина, переваримого протеина, сырой клетчатки, сахара и крахмала. Соотношение сахара-крахмала с переваримым протеином

\section{Citation:}

Chernushkin, B.O., Slivinska, L.G., Vlizlo, V.V. (2016). Indicators of lipids peroxidation in the blood of ewes with hepatodystrophy. Scientific Messenger LNUVMBT named after S.Z. Gzhytskyj, 18, 2(66), 202-205. 
составляло 1,78: 1, а сахаро-протеиновый соотношение - 0,77. Рачионы были дефицитными по содержсанию витаминов D и Е, микроэлементов - Сульфура, Купрума, Цинка, Кобальта и Йода.

У овцематок, больных гепатодистрофией, установлено развитие окислительного стресса - повышение активности ТБК-активных продуктов, гидроперекисей липидов, диеновых коньюгатов. В частности, вдвое возрастала концентрация диеновых коньюгатов, втрое повышалось количество гидроперекисей липидов, а активность ТБК-активных продуктов увеличивалась в 5 раз по сравнению с клинически здоровыми жсивотными.

При гистологическом исследовании биоптатов печени больных овцематок установлено развитие белковой зернистой и жировой дистрофии гепатоичтов.

Ключевые слова: овцьы, гепатодистрофия, окислительный стресс, ТБК-активные продукты, гидроперекиси липидов, диеновые коньюгаты, гепатоииты.

\title{
Indicators of lipids peroxidation in the blood of ewes with hepatodystrophy
}

\author{
B.O. Chernushkin ${ }^{1}$, L.G. Slivinska ${ }^{1}$, V.V. Vlizlo ${ }^{2}$ \\ ${ }^{1}$ Lviv national university of veterinary medicine and biotechnologies named after S. Gzhytskyj \\ Pekarska Str., 50, Lviv, 79010, Ukraine; \\ ${ }^{2}$ Institute of Animal Biology NAAS, \\ V. Stus Str., 38, Lviv, 79034, Ukraine
}

The article deals with the results of studies on the causes and clinical manifestations of hepatodystrophy in ewes, indicators status of lipid peroxidation - TBA-active products, lipid hydroperoxides, diene conjugates.

In order to establish the causes of hepatodystrophy in sheep, we have analyzed the feed rations. Sheep investigated 24 local breeds aged $3-4$ years, weighing $45-56 \mathrm{~kg}$. Conducted clinical study animals and blood were collected for laboratory analysis. Serum sheep determined the content of malondialdehyde (MDA-active products) using thiobarbituric acid (Stalnaja I.D., Haryshvyly T.G, 1977) and lipid hydroperoxides using ammonium thiocyanate (Romanova LA. Stalnaja I.D., 1977). In blood examined diene conjugates (Stalnaja I.D., 1977).

High performance is ensured animals by creating appropriate technical conditions and feeding. Violation of maintenance processes and non-biological nutrition of the cause performance degradation, the spread of disease and culling of animals. Development hepatodystrophy animals observed in animals fed low-quality forage and depraved that contain a number of toxic products of oxidation of fats - aldehydes, ketones, low molecular weight acids, hydroxy acids, which have toxic properties and also due to an unbalanced diet for the main nutrients and biologically active substances

The main causes of primary hepatodystrophy in sheep is imbalanced nutrition and lack of essential nutrients in the diet. In analyzing the diet of established lack of dry matter, raw protein, digestible protein, raw fiber, sugar and starch. Value sugar and starch with digestible protein accounted for 1,78: 1, and sugar-protein ratio-0,77. Rations were scarce for vitamins $D$ and $E$, microelements - Sulphur, copper, zinc, cobalt and iodine.

In ewes suffering from hepatodystrophy was set the development of oxidative stress - increase in blood activity of TBA-active products, lipid hydroperoxides, diene conjugates. In particular, concentration of diene conjugates was increased by twice the number of hydroperoxides lipids was increased by three times and the activity of TBA-active products was increased by five times compared with clinically healthy animals. Histological examination of liver biopsies of ewes was set that the develop of protein granular and fatty degeneration of hepatocytes.

Key words: sheep, hepatodystrophy, oxidative stress, TBA-active products of lipid hydroperoxides, diene conjugates, hepatocytes.

\section{Вступ}

Висока продуктивність тварин забезпечується шляхом створення належних технологічних умов утримання та годівлі. Порушення технологічних процесів утримання і недотримання біологічно повноцінного живлення є причиною зниження продуктивності, поширення захворюваності та вибракування тварин. Розвиток гепатодистрофії у тварин спостерігається при згодовуванні тваринам неякісних і зіпсутих кормів, що містять цілий ряд токсичних продуктів окиснення жирів - альдегіди, кетони, низькомолекулярні кислоти, оксикислоти, які володіють токсичними властивостями, а також внаслідок незбалансованого раціону за основними поживними і біологічно активними речовинами (Dirksen et al., 2002).

Продукти пероксидного окислення ліпідів ведуть до виникнення дистрофічних процесів у цитоплазмі гепатоцитів, окиснюють ненасичені жирні кислоти, які входять до складу мембран, що спричиняє до під- вищення проникності або повну руйнацію оболонки клітин. Збільшення вмісту в крові продуктів перекисного окиснення ліпідів (ПОЛ) пришвидшує ліполітичні процеси, що веде до виникнення жирової інфільтрації печінки. При надлишковому утворенні продуктів пероксидного окиснення ліпідів проходить повна руйнація ненасичених жирних кислот і ацетильних залишків фосфоліпідів, порушення структури і функції білків, що призводить до загибелі клітин організму (Danchuk, 2006).

\section{Матеріал і методи дослідження}

3 метою встановлення причин виникнення гепатодистрофії у овець нами було проведено аналіз раціонів годівлі. Досліджено 24 вівцематки місцевих порід віком 3 - 4 роки, масою 45 - 56 кг. Проводили клінічне дослідження тварин та відбирали кров для лабораторного аналізу. У сироватці крові овець визначали вміст малонового діальдегіду (ТБК-активні продукти) 
3 застосуванням тіобарбітурової кислоти (Стальная И.Д., Гаришвили Т.Г., 1977) та гідропероксидів ліпідів 3 використанням тіоціанату амонію (Романова Л.А., Стальная И.Д., 1977). У гепаринізованій крові досліджували дієнові кон'югати (Стальная И.Д., 1977) (Vlizlo, 2012).

\section{Результати та їх обговорення}

При аналізі раціону вівцематок встановлено дефіцит сухої речовини (на 26,5\%), сирого протеїну (на $15,7 \%$ ), перетравного протеїну (на $16,5 \%$ ), сирої клітковини (на 35,3\%), а також обмінної енергії. Уміст цукру та крохмалю в раціоні овець був забезпечений лише на 47,9\% та 79,4\% від потреби і їх сумарне співвідношення із перетравним протеїном складало 1,78:1, а цукро-протеїнове співвідношення - 0,77. Кількість кальцію і фосфору в раціоні овець перевищувала потребу. Фосфорно-кальцієве співвідношення складало 1:1,58 (за норми 1:1,45-1,60). Проте кількість вітамінів Д і Е у кормах була низькою (відповідно 16,4\% та 59,6\% забезпеченості). При дослідженні мікроелементного складу корму встановлено низьку забезпеченість вівцематок Сульфуром (54\%), Купрумом (58\%), Цинком (77\%), Кобальтом (28\%) та Йодом (77\%).

Клінічними дослідженнями встановлено, що хворі вівцематки погано реагували на зовнішні подразники, часто лежали і важко піднімалися. Температура тіла, частота пульсу та частота дихання не відрізнялися від показників клінічно здорових овець. Розвиток ураження печінки спричинював гіпотонію шлунковокишкового тракту. Так, частота скорочень рубця складала $1,8 \pm 0,42$, порівняно $33,5 \pm 0,16$ у клінічно здорових ( $<<0,01)$. Слизові оболонки у хворих овець були блідо-рожевого кольору, шкіра - еластична, блідого або блідо-рожевого кольору, вовна забруднена, без блиску.

Показники пероксидного окиснення ліпідів у овець, хворих на гепатодистрофію, зростали. Зокрема, концентрація дієнових кон'югатів у крові овець збільшилася удвічі (7,5 $\pm 1,46$ мкмоль/л; рис. 1$)$, порівняно 3 клінічно здоровими тваринами $(3,3 \pm 0,17$; $\mathrm{p}<$ 0,05). Кількість гідропероксидів ліпідів у сироватці крові (рис. 2) хворих підвищувалася більш ніж утричі $\left(7,6 \pm 1,18\right.$ од.Е $\mathrm{E}_{480} /$ мл проти $2,3 \pm 0,19$ од.Е $\mathrm{E}_{480} /$ мл у клінічно здорових; $\mathrm{p}<0,001)$.

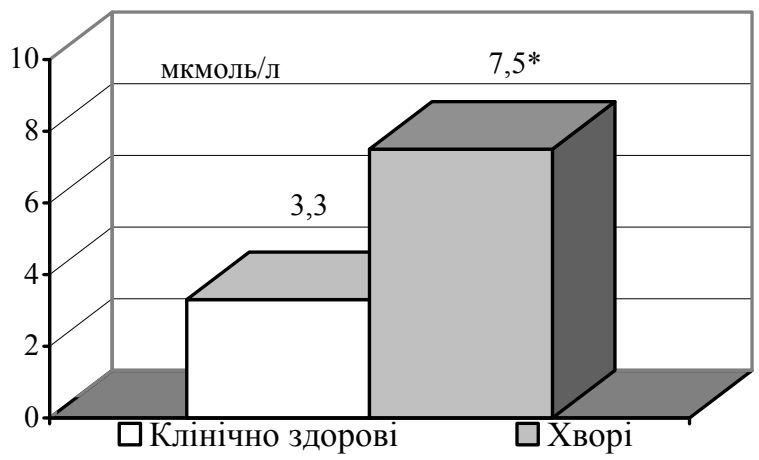

Рис. 1 Вміст дієнових кон'югатів у крові Вівцематок (Примітка. ${ }^{*}-p<0,05$ )

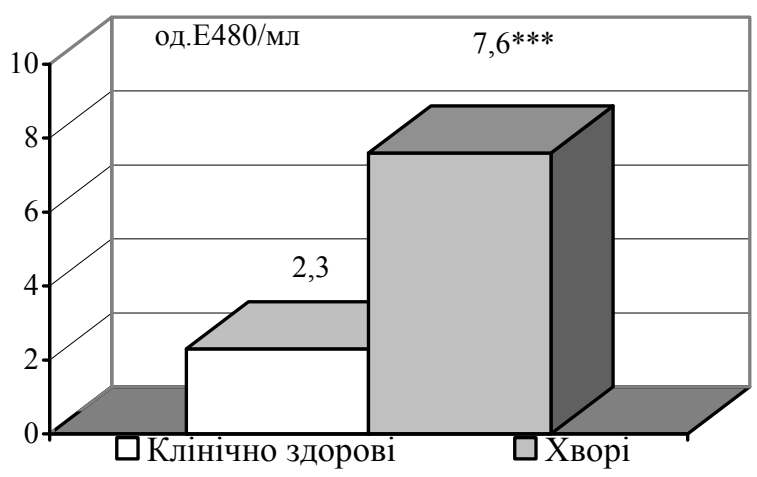

Рис. 2. Вміст гідропероксидів ліпідів у сироватці крові вівцематок (Примітка. *** $-p<0,001)$

Вміст ТБК-активних продуктів у сироватці крові овець (рис.3), хворих на гепатодистрофію, також зростав

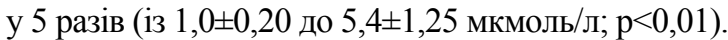

Збільшення продуктів ПОЛ у крові хворих овець вказують на посилене руйнування клітин організму вільними радикалами, у тому числі гепатоцитів (Freeman et al., 1988; Skiba et al., 2005; Kartashov et al., 2010).

При мікроскопічному дослідженні біоптатів печінки хворих овець встановлено набряк гепатоцитів, нечіткі межі клітин, мутність цитоплазми, гіпохромні або лізовані ядра (рис. 4). Реєстрували порушення структури балок та некроз гепатоцитів, що розміщені центролобулярно.

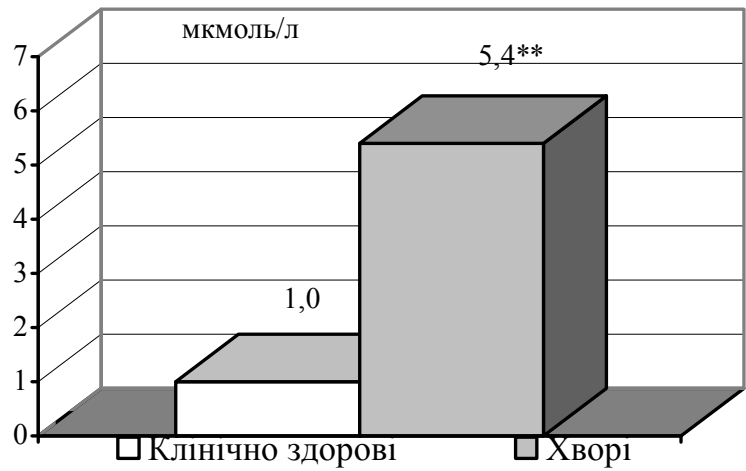

Рис. 3 Вміст ТБК-активних продуктів у сироватці крові вівцематок (Примітка. ** - $<<0,01$ )

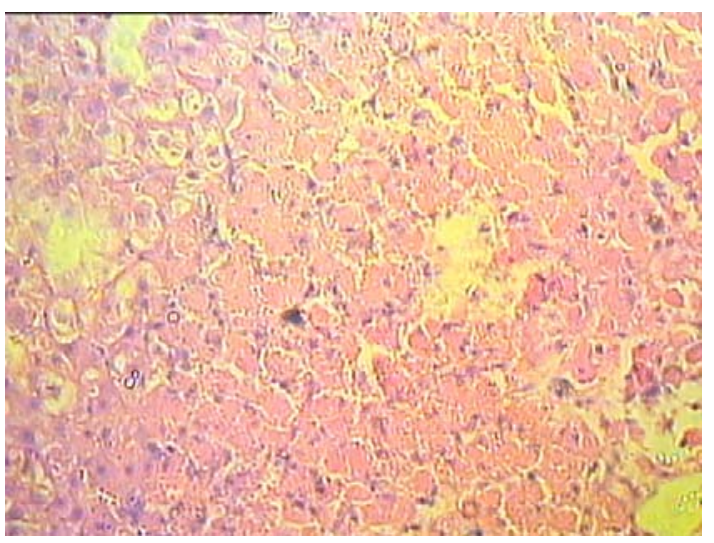

Рис. 4. Структура печінки хворої вівці. Гематоксилін-еозин. х 200 


\section{Висновки}

При аналізі раціону годівлі овець, нами встановлено дефіцит перетравного протеїну, сирої клітковини, цукру, вітамінів - D і E, Сульфуру, Купруму, Цинку, Кобальту та Йоду. Значне підвищення вмісту продуктів пероксидного окиснення ліпідів у крові хворих овець свідчить про наявність оксидаційного стресу. Результати гістологічних досліджень біоптатів печінки свідчать про розвиток білкової зернистої та жирової дистрофії паренхіми печінки.

Перспективи подальших досліджень полягають у дослідженні особливостей морфофункціонального стану печінки у овець за первинної та вторинної гепатодистрофії.

\section{Бібліографічні посилання}

Dirksen, G., Gründer, H.-D., Stöber, M. (2002). Innere Medizin und Chirurgie des Rindes. Berlin: Parey.

Vlizlo, V.V. (2012). Laboratorni metodi doslidzhen' u biologii, tvarinnitstvi ta veterinarniy meditsini (dovidnik). L'viv, SPOLOM (in Ukrainian).

Danchuk, V.V. (2006). Peroksidne okisnennya u sil's'kogospodars'kikh tvarin i ptitsi. Kam'yanets'Podil's'kiy: Abetka (in Ukrainian).

Kartashov, M.I., Timoshenko, O.P., Kibkalo, D.V. (2010). Veterinarna klinichna biokhimiya: navchal'niy posibnik. Kharkiv: Espada (in Ukrainian).

Skiba, O.O. Bereza, V.I., Dolets'kiy, S.P., Golopura, S.I., Tsvilikhovs'kiy, M.I. (2005). Porushennya obminu rechovin $\mathrm{u}$ tvarin pid vplivom ekologichnikh chinnikiv. Visnik agrar. Nauki. 4, 53-55 (in Ukrainian).

Freeman, A., Boobis, A.R., Gooderham, N.J. (1988). Hepatotoxicity of carbon tetrachloride: protection by pretreatment of mice with polyriboinosinic acid - polyribocytidylic acid. Biochem. Soc. Trans. 216(4), 632-633.

Rosen, G.M., Rauckman, E.I. (1982). Carbon tetrachloride induced lipid peroxidation: a spin trapping study. Toxicol. Lett. 210(10), 337-344.

Стаття надійшла до редакиії 24.09.2016 